\title{
LEGAL ANALYSIS OF BANKRUPTCY IN THE PERSPECTIVE OF LEGAL PURPOSES
}

\author{
Theresia Anita Christiani \\ Atma Jaya University Yogyakarta \\ anita.christiani@uajy.ac.id
}

\begin{abstract}
Law Number 37 Of 2004 On Bankruptcy And Suspension Of Obligation For Payment Of Debts was formed to protect creditors and debtors. The purpose of Law is to realize the value of the benefit, justice, and legal certainty. This juridical fact shows that there are legal issues that deserve to be studied normatively. Based on the above background, the problem in this research is the right proposal concept. The application of articles 2 (1) and Article 8 (4) Bankruptcy And Suspension Of Debt Payment Obligations Law can achieve legal objectives. The results showed that the proposed concept to amend the Bankruptcy And Suspension Of Debt Payment Obligations Law took time. Concrete conceptual proposals so that the application of articles a (1) and Article 8 (4) can realize values by changing the attitude of judges who decide not only based on legal certainty. The Judge's attitude in deciding must also be based on the potential impact of Bankruptcy on the Debtor, whether it will lead to benefit or justice. The constitutive nature of decisions also affects changes in judge attitudes.
\end{abstract}

Keyword: Legal Analysis; Bankruptcy; Legal Purposes.

\section{A. INTRODUCTION}

The Law Number 37 of 2004 concerning Bankruptcy and Suspension Obligation For Payment Of Debts is a juridical basis for the arrangement of Bankruptcy and debt payment obligations. The juridical process runs a fair, fast, open, and effective manner ${ }^{1}$ bankruptcy and suspension of debt payment obligations law revokes Verordening ter Invoering van De Faillissements Verordening (FV) and Law Number 4 of 1998 concerning Bankruptcy $^{2}$. The bankruptcy institution is a realization of Articles 1131 and 1132 of the Civil Code. It can also be said that the bankruptcy and suspension of debt payment obligations law is further regulation of articles 1131 and 1132 of the Civil Code.

Law Number 37 of 2004 was born to provide legal protection for Debtors and Creditors. Legal protection for debtors and creditors can be seen from the requirements, procedural process, evidence, settlement, and settlement. In Indonesia's practice, bankruptcy decisions that are given do not always protect debitors. For example, the case of the Semarang District

1 John A. E. Pottow, What Bankruptcy Law Can and Cannot Do for Puerto Rico, Rev. Jur. U. P. R. 85, no. 3, 2016, page.689-704

2 Brouwer, M. Eur J Law Econ, Reorganization in the US and European Banking Law, Journal of Law and Economics 22 (1) 2006, page 5-20 
Court Decision Number 11/PdtSus/Pailit/2017.PN Niaga Semarang 2017 in conjunction with Number 01/PdtSus/PKPU/2015/ PN Niaga Semarang Concerning the case for the cancellation of peace at the first level between Hendriarto Bambang Santoso and PT Perindustrian Nyonya Meneer. Another example is the Commercial Court Decision in PT Telkomsel Selluler against PT Prima Jaya Informatika, Decision Number 11 / Pdt. Sus-Pailit / 2017 / PN Niaga Smg jo. Number 01 / Pdt.Sus-PKPU / 2015 / PN Niaga Smg and Decision at Cassation level No. 704 / K / Pdt.Sus / 2012 jo. Ministry of Military Review Decision Number 30 PK / Pdt.Sus.Pailit / 2013. The decision of the Commercial Court distorted its implementation towards legal objectives of realizing certainty, justice, and benefit. This juridical fact shows that there are legal issues that deserve to be studied normatively.

\section{B. RESEARCH METHODS}

This research was normative juridical research and used secondary data. A qualitative data analysis technique was used. Data in the form of primary and secondary legal materials as well as data obtained from information from informants are collected and systematized, then described and analyzed. The data obtained will be analyzed using qualitative analysis using the concept of legal theory and legal philosophy to answer the problem. The approach method used in analyzing data and problems is the comparative and regulatory approach. Thinking process in drawing conclusions using deductive thinking processes.

\section{RESULT AND DISCUSSION}

\section{Overview of Legal Purposes}

Not all schools of Law discuss the objectives of Law. The purpose of Law is a characteristic of natural Law because natural Law deals with transcendent and metaphysical matters. ${ }^{3}$ Natural Law in this case, is also called natural Law (from now on in this study, the term natural law is used. The concept of natural law answers the question, "what makes law a law?" The answer to that question is that a moral theory is based on the philosophy of human nature. According to Sonny Keraf, citing the opinion of Frans Magnis-Suseno,) He states that the main service of Natural Law (theory) is that it becomes the basis for the application of every positive law, on the grounds: ${ }^{4}$ "This theory guarantees the validity of the optimal social order because it places favorable laws in human nature. This theory demands that every Law that applies to humans must be based on and in line with human nature. In other words, a positive law can only be said to be valid if it is following the essential requirements and natural human tendencies.

The importance of natural law in the formation of positive law was described by E. Sumaryono ${ }^{5}$ Said that natural Law as the basis for

3 Peter Mahmud Marzuki, Pengantar IImu Hukum, Kencana Media Group, Jakarta, 2014, page. 97.

4 E.Fernando M.Manullang, Menggapai Hukum Berkeadilan, Kompas, Jakarta, 2007, page. 156.

5 E. Sumaryono, Etika dan Hukum, Kanisius, Yogyakarta, 2002, page. 217. 
enacting positive law provides a philosophical basis for enacting a positive law, poured into legal principles. Every legal formation must be based on general principle principles. It shows that the contribution of natural Law has led to a rational basis for the enactment of positive Law. Every positive Law also contains philosophical values and does not necessarily contain technical standards and strict rules Satjipto Raharjo ${ }^{6}$ Also said that natural law contains norms (as substance), but natural Law can function as a method of making reasonable regulations. These opinions show the strong influence of natural law thinking, which recognizes the existence of natural legal bases for enacting an excellent or positive legal rule.

In connection with the previous description that is talking about the purpose of Law, Gustav Radbruch acknowledges a law above positive Law, which acts as a legal order norm; Radbruch further said that: "The definition of Law can be divided into 3 (three) aspects, all of which are necessary to arrive at an adequate legal meaning. The first aspect is justice in a narrow sense. This justice means equal rights for all people before the court. The second aspect is the goal of justice or finality. This aspect determines the purpose of the LawLaw's content because the Law's content is following the objectives to be achieved. The third aspect is legal certainty or legality. This aspect ensures that the Law can function as a rule that must be obeyed."

The order of these three aspects is determined by Radbruch as follows: justice, legal certainty, and finality. Radbruch's opinion earlier emphasized that justice is an aspect that forms the basis for legal certainty and finality

\section{Faculties That Encourage Legal Change}

The dynamics of rapid economic development demand the dynamics of legal arrangements to protect related economic actors. According to Roscoe Pound's teaching, Law has seen from its function that Law is a tool of social engineering (Law as a tool for reforming society). The function of Law as a tool for reforming society has the consequence that Law must be a tool or means to be able to change and renew society as it aspires to be. The consequence of the Law's function as a tool for reforming society is that the laws that regulate and direct society's development must come before changes in society. Legal formers should always be forward-looking. In today's economic development, facing various societal changes that require legal certainty in regulating these changes, it is more accurate to say that Law can manipulate and change society in the sense of Law. Lawmakers must be forward-oriented in the sense that they can predict society's future development so that Law's purpose is to provide certainty and justice and benefit can be realized.

6 Satjipto Raharjo, IImu Hukum (Cetakan Kedelapan), PT Citra Aditya Bakti, Bandung, 2014, page.261. 
Talcott Parson's ${ }^{7}$ Cybernetic theory shows that in society, there are 4 (four) sub-systems, including

a. The cultural system.

b. Social system

c. Political system

d. Economic system

Parson's view presents cybernetic relationships to give names to automated control processes. This control process can be seen in various fields. The cybernetic relationship between the sub-systems in society occurs through information flow from the sub-system with a high level of information; in this case, it is conditioned by the sub-system with a lower information level. The reverse flow also occurs. The sub-system with a higher level of information, in this case, is controlled by a sub-system that has a lower ability to provide information. The political and economic sub-system has a lower level of information than the social sub-system. However, the economic and political sub-system has more energy than cultural sub-system. It can explain how the economic and political sub-systems influence law as a social system in society in the operation of Law to achieve specific values. The cybernetic theory is described as having more incredible energy to direct and control the Law in achieving values. Thus, the Law is always required to change support of the rapid economy so that Law's purpose is to protect parties in the economy can run well.

3. Law Number 37 Concerning 2004 From The Legal Objectives and Requirements for Debtors To Be Declared Bankrupt

a. The Purpose Of The Existence Of Law Number 37 Concerning the Year 2004 Concerning Bankruptcy and Delay of Debt Payment Obligations

Bankruptcy and Suspension of Debt Payment Obligations Law is the realization of articles 1131 and 1132 of the Civil Code. These articles contain things that state that in a situation where the Debtor does not want to pay his debt voluntarily. Even though the court decision punished him for paying off his debt, the Debtor cannot pay debts. Their assets will be confiscated without exception, (general confiscation) for sale, where the proceeds from the sale are distributed to all creditors with an amount based on the number of each creditors' receivables, except for creditors who are prioritized by Law, as regulated in Articles 1134 and 1135 of the Civil Code.

The purpose of bankruptcy ${ }^{8}$ is not explicitly stated in the bankruptcy and suspension of debt payment obligations law. The General Section of the Elucidation of the bankruptcy and suspension of debt payment obligations law states as follows: There are several factors that need to regulate Bankruptcy and postponement of debt payment obligations: First, to avoid seizing the Debtor's assets if at

7 Ibid, page. 134.

8 Michael T, Debtor States and an International Bankruptcy Court: The IMF Creditor Problem, Chicago Journal of International Law: Vol. 4: No. 1 2003, Article 19. 
the same time there are several creditors who collect their receivables from the debtor Second, to avoid the existence of a creditor who holds the right to guarantee material claiming his rights by selling the Debtor's property without paying attention to the interests of the Debtor or other creditors. Third, to avoid fraud committed by one of the creditors or debtors themselves. For example, the Debtor tries to benefit one or several certain Creditors so that other Creditors are harmed, or there is fraudulent action by the Debtor to run away all of his assets with the intention of releasing his responsibility to Creditors. The objective of Bankruptcy is to protect both Creditors and Debtors.

b. Definition of Bankruptcy

The definition of Bankruptcy ${ }^{9}$ Is contained in Article 1 paragraph (1) bankruptcy and suspension of debt payment obligations law states that: Bankruptcy is general confiscation of all assets of the bankrupt Debtor whose management and settlement is carried out by a curator under the supervision of the supervisory Judge as regulated in this Law.

As reviewed in this article, the definition of Bankruptcy is the process of general confiscation of the Debtor's assets. The Debtor, who has more than one Creditor, cannot carry out his obligations at the due date and can be collected. After the Debtor is declared bankrupt, the management and management of the Debtor's assets are carried out by the curator. Of course, it is to prevent injustice that might occur if the Debtor or Creditor carries out the management and settlement.

c. Requirements For A Debtor To Be Declared Bankrupt

The conditions for a debtor to be filed for Bankruptcy are as stipulated in Article 2 paragraph (1) of Bankruptcy and Suspension of Debt Payment Obligations Law: A debtor with two or more creditors and does not pay off at least one debt due and can be collected declared bankrupt by a court decision, the request of one or more creditors. From the provisions of Article 2, the conditions for a Debtor can be filed for bankruptcy if:

1) Debtor has more than one Creditor.

2) The Debtor does not pay off at least one debt that is past due and can be collected.

3) Declared Bankruptcy with a court decision.

Article 1 paragraph (1) Bankruptcy Law and PKPU referred to as Debtor: a person who has a debt due to an agreement or Law, the settlement of which can be collected before the court. Creditor's definition is regulated in Article 1 paragraph (2) Bankruptcy Law -

9 Adegbemi Babatunde Onakoya, Ayooluwa Eunice Olotu, Bankruptcy and Insolvency, an Exploration of Relevant Theories, International Journal of Economics and Financial Issues, 2017, 7(3), page.706-712. 
PKPU, namely people who have receivables due to agreements or laws that can be collected before the court. According to Article 2, paragraph (1) Bankruptcy and Suspension of Debt Payment Obligations Law, one of the conditions that must be fulfilled is that a debtor must have two or more creditors. So there must be other creditors apart from creditors who apply for Bankruptcy and Suspension of Debt Payment Obligations Law. This law only allows a Debtor to be declared bankrupt if the Debtor has at least 2 (two) Creditors.

The definition of debt is also stated in Article 1, paragraph (6) Bankruptcy and Suspension of Debt Payment Obligations Law. Debt is stated as an obligation stated or can be stated in an amount of money. It can be either in Indonesian currency or foreign currency, either directly or in the future. Alternatively, contingents that arise due to an agreement or Law must be fulfilled by the Debtor. If not complied with by the Debtor and if not fulfilled, give the Creditor the right to obtain fulfillment from the Debtor's assets. The Act elucidation of Article 2 paragraph (1) of the Bankruptcy and Suspension of Debt Payment Obligations Law states that debt that has matured and can be collected is the obligation to pay debts. That has matured well because they have been promised, due to the acceleration of the collection period as agreed, due to the imposition of sanctions or fines by competent agency and the arbiter court arbiter council's decision.

The application for a bankruptcy statement must be proven (simple proof) according to what is stipulated in Article 8 paragraph (4) Bankruptcy and Suspension of Debt Payment Obligations Law. The simple proof is a simple proof of the existence of a minimum of one debit or debt that has matured and the existence of two or more creditors.

Article 2 of the Bankruptcy Law's provisions concerning the requirements for debtors to be eligible for Bankruptcy contain relatively easy requirements to fulfill to file a bankruptcy application. It is also supported by simple proof principles related to Article 8, paragraph (4)

\section{Analysis Of Judges' Decisions In The Bankruptcy Case Of PT Telkomsel And PT Perindustrian Nyonya Meneer in a Legal Purpose Perspective}

a. Review of Judges' Decisions in PT Telkomsel's Bankruptcy Application.

1) Parties

a) PT. Telecommunication Cellular.

b) PT. Prima Jaya Informatics.

2) Verdict

The Commercial Court Decision at the Central Jakarta District Court Number: 48/PAILIT/2012/PN.NIAGA.JKT.PST, Decision on special civil cases (Bankruptcy) in Cassation Level No. 
704 K / Pdt.Sus/ 2012, and Decision Review Number 30 PK / Pdt.Sus.Pailit bank/2013, in a special civil case requesting a bankruptcy statement, Juridical facts show:

a) The Commercial Court Decision at the Central Jakarta District Court Number: 48 / PAILIT / 2012 / PN.NIAGA.JKT.PST, among others, resulted in the Principal of the Case Granting the Bankruptcy Petitioners' Petition for Bankruptcy Declaration against the Respondent for Bankruptcy and Declaring the Respondent for Bankruptcy, namely PT. Telekomunikasi Seluler, a limited liability company engaged in the telecommunications services business, is bankrupt with all its legal consequences.

b) Decision No. 704 K / Pdt.Sus / 2012, a particular civil Law's (Bankrupt the Cassation Level. The Cassation Decision has resulted in the decision to grant the Cassation Petitioner's cassation petition: PT. Telecommunication Cellular;

- Granted the Cassation Petitioner: PT. Telecommunication Cellular;

- To cancel the Commercial Court decision at the Central Jakarta District Court Number: 48 / PAILIT / 2012 / PN.NIAGA.JKT.PST. September 14, 2012;

c) Decision Number 30 PK / Pdt.Sus.Pail bank / 2013, a particular civil case requesting a bankruptcy statement at the review examination:

- Rejecting the petition for reconsideration from the Petitioner for Reconsideration of PT. Prima Jaya Informatics;

- Sentenced the Reconsideration Petitioner / Bankruptcy Petitioner to pay the court fee in this reconsideration examination of Rp.10,000,000.00 (ten million rupiahs).

The verdict relating to the bankruptcy status of PT Telkomsel shows a different decision in the verdict at the commercial court at the District Court, with the decision at the Cassation Level, the verdict was upheld in the Judge's decision in Judicial Review.

In the decision in the District Court, the Judge decided that PT.Telkomsel was in Bankruptcy. The Judge will use the provisions of Article 8 paragraph (4) bankruptcy and suspension of debt payment obligations law, which reads: "The application for a bankruptcy statement must be granted if there are facts or circumstances that simply prove that the requirements to be declared bankrupt as referred to in Article 2 paragraph (1) have been fulfilled."

Elucidation of Article 8 paragraph (4) bankruptcy and suspension of debt payment obligations law provides the following explanations: Referred to as "simply proven facts or circumstances" are the facts of two or more Creditors and facts of overdue and unpaid debts. Meanwhile, the difference in the amount of debt 
claimed by the applicant for Bankruptcy. The respondent for Bankruptcy does not prevent the decision to declare Bankruptcy.

This article is the basis for the JudgeCommercial Court Judge in whether or not to grant a bankruptcy request. The Judge must grant Bankruptcy's declaration if some facts or circumstances simply prove to be declared bankrupt. The facts or circumstances are contained in Article 2 paragraph (1) Bankruptcy and Suspension Of Debt Payment Obligations Law, which reads: "A debtor who has two or more creditors and does not pay off at least one debt which is due and can be collected is declared bankrupt by a court decision, his request, at the request of one or more creditors."

Furthermore, the explanation of Article 2 Bankruptcy and Suspension Of Debt Payment Obligations Law provides the following explanation: What is meant by "Creditors" in this paragraph are either concurrent creditors, separatist creditors, or preferred creditors. Particularly regarding separatist creditors and preferred creditors, they can apply for a bankruptcy statement without losing the collateral rights for the property they own against the Debtor's assets and their right to take precedence. If there is an indication of creditors, each Creditor is a creditor, as referred to in Article 1 number 2 Bankruptcy and Suspension Of Debt Payment Obligations Law. What is meant by "debts that have matured and are collectible" is the obligation to pay debts that have matured. From Article 2 paragraph (1) and Article 8 paragraph (4) Bankruptcy and Suspension Of Debt Payment Obligations Law, along with the explanation of each of the above articles, it can be examined that the will of the legislators, that what is meant by simple proof, is the fact of two or more creditors and facts. Past due and unpaid debts must be proved simply. It means that what must be proven simply is two or more creditors and that debts have matured and are not paid. In this regard, the Judge must grant the decision to declare Bankruptcy if it can be simply proven by the facts of two or more creditors and the fact that debts that have matured and are not paid must be proved simply.

In this regard, the Decision of the Commercial Court at the Central Jakarta District Court Number: 48 / PAILIT / 2012 / PN.NIAGA.JKT.PST, among other things, decided to grant the Bankruptcy Petitioners' Petition for Bankruptcy Declaration against the Bankrupt Respondent in its entirety. It means that the panel of judges has succeeded in proving the fact of two or more creditors and that debts that have matured and are not paid must be proved simply. By Ignoring the situation, whether the facts of two or more creditors and the fact of debts that have matured and are not paid must be simply proven. It is the debate of the parties. The Judge should apply what the meaning desired by Article 8 and Article 2 of bankruptcy and suspension of debt payment obligations law in the framework of achieving The purpose of Bankruptcy is is to protect 
debtors and creditors. However, it can be seen, in fact, the impact of the Judge's decision at the Central Jakarta Commercial Court. The bankruptcy decision's impact is enormous when viewed from consumer protection, from the investment climate aspect, which is an essential development factor in Indonesia.

The Judge Commercial Court Central Jakarta, who decided PT Telkomsel's Bankruptcy, can be examined from consumer interests. The pragmatic impact is that millions of Telkomsel users will be affected by the PT Telkomsel bankruptcy decision. On the other hand, communication is essential in today's society. From the perspective of legal protection for consumers, this website is related to Article 19 of Act Number 8 of 1999 concerning Consumer Protection. From the Bankruptcy Law perspective, the bankruptcy position of PT Telkomsel Consumers Telkomsel will be categorized as a permanent creditor. They will receive their rights. after the bankruptcy process has gone through the stages of a bankruptcy application, verification meetings, reconciliation, accurate homologation, insolvency, liquidation, after the process will be given rights to consumers. There is predict the length of the process that must be passed in implementing the fulfillment of creditors' rights due to debtors' Bankruptcy. Reviewing the implementation of the Debtor's bankruptcy decision against consumers who are in the position of a conscientious creditor, the Judge must consider not only the verdict from the aspect of legal certainty but also from the sociological aspect and its impact in the broader community. Judges need to consider whether a debtor's bankruptcy decision can protect creditors and debtors as the meaning desired by the legislators, as stated in Article 8 and Article 2 of the bankruptcy and suspension of debt payment obligations law.

b. Review of Judges' Decisions in the Bankruptcy Decision of PT. Njonja Meneer Industry

1) Parties

a) PT Perindustrian Njonja Meneer or abbreviated as PT Njonja Meneer (Respondent Party)

b) Hendrianto Bambang Santoso (Petitioner's Party)

2) Verdict

a) Decision Number 11 / Pdt.Sus-Pailit / 2017 / PN Niaga Smg jo. Number 01 / Pdt.Sus-PKPU / 2015 / PN Niaga Semarang.

This decision is a decision to cancel the peace. The application for this decision previously contained a Case registered in Case Number 01 / Pdt registration. Sus-PKPU / 2015 / PN Niaga Smg, at the Commercial Court at the Semarang District Court. PT.Citra Sastra Grafika has submitted an Application for Postponement of Debt Payment Obligation and PT Nata Meridian Investara towards PT.Perindustrian Njonja Meneer or abbreviated as PT Njonja Meneer. According to Article 170 paragraph (1) of Law Number 37 of 2004 concerning Bankruptcy and Postponement of Debt Payment 
Obligations states: Creditors can demand the cancellation of a peace that has been passed if the Debtor fails to fulfill the contents of the peace.

Based on Article 291 paragraph (2) of Law Number 37 the Year 2004 concerning Bankruptcy and Postponement of Debt Payment Obligations, it states that "In the Court's decision canceling the peace, the Debtor must also be declared bankrupt." Based on these facts, the Semarang District Court Judge decided to: cancel the peace agreement and declare the Respondent (PT Perindustrian Nyonya Meneer) in Bankruptcy.

b) Cassation Decision Number 1397 K / Pdt.Sus-Pailit / 2017

Regarding the Judge's decision canceling the peace agreement and declaring the Respondent (PT Perindustrian Nyonya Meneer) in Bankruptcy, the Petitioner applied cassation on August 10, 2017, as evidenced by the Deed of Cassation Application Number 01 / Pdt. Sus-PKPU / 2015 / PN Niaga Smg, in conjunction with Number 11 / Pdt.Sus-Pailit / 2017 / PN Niaga Smg, in conjunction with Number 04 / Pdt.Sus-Pailit / K / 2017 / PN Niaga Smg ,. In essence, the decision on the appeal submitted by PT Perindustrian Nyonya Meneer contained, rejecting the cassation petition from PT Perindustrian Njonja Meneer or abbreviated as PT Njonja Meneer must be: ${ }^{10}$ It means that the Commercial Court Decision declares Bankruptcy of PT Perindustrian Njonja Meneer or abbreviated as this Supreme Court Cassation Decision strengthens PT Njonja Meneer. Dr.Sutan Remy Sjahdeini, ${ }^{11}$ Bankruptcy institutions should only be an ultimum remedium. So, Judex Facts has neglected to apply the Law because Bankruptcy can only be imposed if there is no other step to settle the Debtor's obligations to creditors and that Bankruptcy is the only way. In connection with this PT Perindustrian Nyonya Meneer bankruptcy decision, the Judge should also have seen the impact that the bankruptcy decision had on thousands of employees affected by its Bankruptcy. It should also be considered that PT Perindustrian Nyonya Meneer, a legendary company that is a nation's asset, should be capable and outbox judges.

From the two bankruptcy cases, many bankruptcy cases occurred after the birth of Law no. 37 of 2004. There are problems related to the implementation of article 2 jucto article 8 of the bankruptcy and suspension of debt payment obligations law is a consideration for judges in deciding the Bankruptcy of a legal subject. Whereas, even though the requirements contained in Article 2 have been fulfilled in

10 Source ,https://putusan.mahkamahagung.go.id/putusan/fb440824b3e9aae938 96f0e804ea06b9, accessed 10 Maret 2018.

11 Sutan Remy Sjahdeini, S.H., 2002, Hukum Kepailitan, page. 59 
making a decision, the Judge must adhere to the value of the value contained in Article 2 jucto Article 8. The purpose of Bankruptcy is to provide legal protection to debtors and creditors to be considered by judges in making decisions. It is also based on the explanation of Article 5 paragraph (1) of Law no. 48 of 2009 concerning Judicial Power states that judges and judges of the constitution must explore, follow, and are also obliged to understand the traditional value of society and the sense of justice that lives in society. Based on this, justice does not always have to be measured by justice based solely on legal norms. When viewed from the history of changes, the focus is on protecting creditors' interests in an economic crisis. This historical background then forms the straightforward concept of requirements for debtors to become bankrupt. The regulation of the elementary bankruptcy requirements in empirical facts based on the understanding of the case above has not shown the Law's realization through a judge's decision, bringing justice and benefit to the parties. The impact of the Judge's decision on both the Bankruptcy of PT Telkomsel (although later the verdict was corrected at the cassation level and included in a review) and PT Nyonya Meneer.

An amendment Of bankruptcy and suspension of debt payment obligations law is an ideal solution. It needed which can adjust to the development and situation of economic activity. However, this proposal will be difficult to realize. It is because, in Indonesia, the Law's amendment process is juridical and political. This process requires a long time and queues. A concrete suggestion in dealing with these facts is that in deciding a bankruptcy application based on the provisions of the bankruptcy and suspension of debt payment obligations law, it is important to have the attitude of the Judge and the Judge's conviction to consider aspects of legal protection for the Debtor. Improving the quality of judges is a priority ${ }^{12}$, . Based on this, the impact on debtors of potential bankruptcy decisions is a matter that should be considered by judges. ${ }^{13}$ The constitutive nature of the bankruptcy settlement, which will impact debtors and creditors, is good to be considered. The Judge's role is essential concerning the

12 Bob Wessels, Energising courts to continue breaking new ground in insolvency and restructuring cases, International Insolvency Review, Volume29, Issue3 August 2020; 125.

13 Prusak, B., Review of Research into Enterprise Bankruptcy Prediction in Selected Central and Eastern European Countries. Int. J. Financial Stud. 2018; Marriana S, Financial Bankruptcy across European Country, International Journal of Economics and Finance, Vol 9 No 7., Nora Muñoz-Izquierdo \& María-del-Mar Camacho-Miñano \& María-Jesús SegoviaVargas \& David Pascual-Ezama, Is the External Audit Report Useful for Bankruptcy Prediction? Evidence Using Artificial Intelligence, International Journal of Financial Studies, MDPI, Open Access Journal, vol. 7(2), 2019; 
benefits of the Judge's decision, which will be the Judge's consideration in making a bankruptcy decision.

\section{CONCLUSION}

Bankruptcy and Suspension of Debt Payment Obligations Law No. $37 / 2004$ were established to resolve the post-monetary crisis. The situation at that time required speedy handling without the will to ignore legal certainty. The facts show that the application of Law No. 37/2004 is no longer able to support the legal objectives of realizing the value of legal certainty, benefit, and certainty. There are developments and changes in society and its economic activities that demand ideal proposals for amendments to the bankruptcy and suspension of debt payment obligations law. This ideal proposal becomes difficult to implement immediately because amendments to the law are part of a political process. Based on this, it is essential for judges to always have an attitude and belief in making bankruptcy decisions based on ordinary justice. A bankruptcy decision's potential impact should be an essential consideration for a judge in delivering a bankruptcy decision. Such attitudes of judges are essential concerning the constitutive nature of bankruptcy decisions.

\section{Books:}

\section{BIBLIOGRAPHY}

A.Sonny Keraf, 1997, Hukum Kodrat dan Teori Hak Milik Pribadi, Kanisius, Yogyakarta;

E. Sumaryono, 2002, Etika dan Hukum, Kanisius, Yogyakarta;

E.Fernando M.Manullang, 2007, Menggapai Hukum Berkeadilan, Kompas, Jakarta;

James Jamaslin Purba, SH, M.H, 2017, Instrumen Kepailitan dan PKPU Sebagai Perlindungan Hukum Bagi Kreditur dan Debitur, Seminar Nasional Kepailitan FH UAJY, Yogyakarta;

Peter Mahmud Marzuki. 2014, Pengantar IImu Hukum, Kencana Media Group, Jakarta;

Satjipto Raharjo. 2014, IImu Hukum (Cetakan Kedelapan), PT Citra Aditya Bakti, Bandung.)

Sutan Remy Sjahdeini, S.H., 2002, Hukum Kepailitan,

\section{Journals:}

Adegbemi Babatunde Onakoya, Ayooluwa Eunice Olotu' 2017, Bankruptcy and Insolvency, an Exploration of Relevant Theories, International Journal of Economics and Financial Issues, 7(3), 2017;

Brouwer, M. Eur J Law Econ, Reorganization in the US and European Bankruptcy law European Journal of Law and Economics, volume 22, 2006; 
Hilgers, Michael T., Debtor-States and an International Bankruptcy Court: The IMF Creditor Problem, Chicago Journal of International Law. Vol. 4: No. 1, 2003;

John A. E., What Bankruptcy Law Can and Cannot Do for Puerto Rico, Rev. Jur. U. P. R. 85, no. 3, 2016;

Marriana S., Financial Bankruptcy across European Country, International Journal of Economics and Finance, Vol 9 No 7, 2017;

Nora Muñoz-Izquierdo \& María-del-Mar Camacho-Miñano \& María-Jesús Segovia-Vargas \& David Pascual-Ezama, "Is the External Audit Report Useful for Bankruptcy Prediction? Evidence Using Artificial Intelligence," International Journal of Financial Studies, MDPI, Open Access Journal, vol. 7(2), 2019;

Prusak, B., Review of Research into Enterprise Bankruptcy Prediction in Selected Central and Eastern European Countries. Int. J. Financial Stud. 2018;

Wessels, B., Energising courts to continue breaking new ground in insolvency and restructuring cases. Int Insolv Rev. 2020;

Website:

https://putusan.mahkamahagung.go.id/putusan/fb440824b3e9aae93896f0e804 ea06b9, accessed 10 Maret 2018 